\title{
ŠOLSKA GEOGRAFIJA V LUČI VZGOJE IN IZOBRAŽEVANJA ZA TRAJNOSTNI RAZVOJ
}

\author{
dr. Karmen Kolnik \\ Oddelek za geografijo, Filozofska fakulteta Univerze v Mariboru \\ Koroška c. 160, SI-2000 Maribor \\ e-mail: karmen.kolnik@uni-mb.si
}

Pregledni znanstveni članek

COBISS 1.02

\section{Izvleček}

$\mathrm{Na}$ osnovi nacionalnih smernic vzgoje in izobraževanja za trajnostni razvoj (VITR) smo v Sloveniji prenovili šolske kurikule, vključno z učnimi načrti za geografijo. Pri VITR si prizadevamo za močno socio-ekonomsko in okoljsko ozaveščenost ter državljansko pripravljenost za posameznikov osebni angažma pri reševanju problemov. V članku je predstavljena soodvisnost akterjev VITR pri doseganju ciljev in razvoju kompetenc učencev na primeru pouka geografije, s posebnim poudarkom na zastopanosti enajstih načel vzgoje in izobraževanja za trajnostni razvoj. Kot izbran primer smo analizirali prenovljeni učni načrt za geografijo v gimnazijah z 210-urnim programom.

Ključne besede: geografija, vzgoja, izobraževanje, učni načrt, gimnazija, načela trajnostnega razvoja

\section{SCHOOL GEOGRAPHY FROM THE VIEWPOINT OF UPBRINGING AND EDUCATION FOR SUSTAINABLE DEVELOPMENT}

\begin{abstract}
The school curricula were revised in Slovenia on the basis of national guidelines of upbringing and education for sustainable development (VITR), including syllabi for geography. The main aim of the VITR is a strong socio-economic and environmental awareness and the willingness of citizens for personal engagement in the solving of problems. The paper presents the interdependence of the VITR agents in the achievement of goals and the development of students' competences in the case of geography classes, with a special emphasis on the eleven principles of upbringing and education for sustainable development. We analyzed the revised syllabus for geography in grammar schools with a 210-hour programme.
\end{abstract}

Keywords: geography, upbringing, education, syllabus, grammar school, sustainable development principles 


\section{UVOD}

Geografsko izobraževanje za prihodnost temelji na spoznanjih in načinih dela, ki so pomembni za sedanjost (učenje o prostoru) in prihodnost (sonaravno trajnostno upravljanje s prostorom). To je eno izmed temeljnih sporočil, ki jih lahko že več kot desetletje povzamemo po mnogih mednarodnih dokumentih (medmrežje 1), različnih geografskih združenjih (Mednarodna geografska zveza (IGU), Evropsko združenje Eurogeo in Herodot) in po ugotovitvah posameznih raziskovalcev (Hawkes 2001; Houtsonen 2004). Za doseganje teh ciljev morajo biti v sozvočju vsi elementi in akterji izobraževalnega procesa (slika 1), kar pa zahteva temeljit razmislek o njihovi današnji vlogi in prav gotovo tudi določene spremembe v celotni nacionalni izobraževalni politiki.

Slika 1: Soodvisnost elementov in akterjev izobraževanja za doseganje ciljev trajnostnega razvoja na primeru pouku geografije

Figure 1: Interdependence of elements and actors of education to achieve sustainable development goals in the case of teaching geography

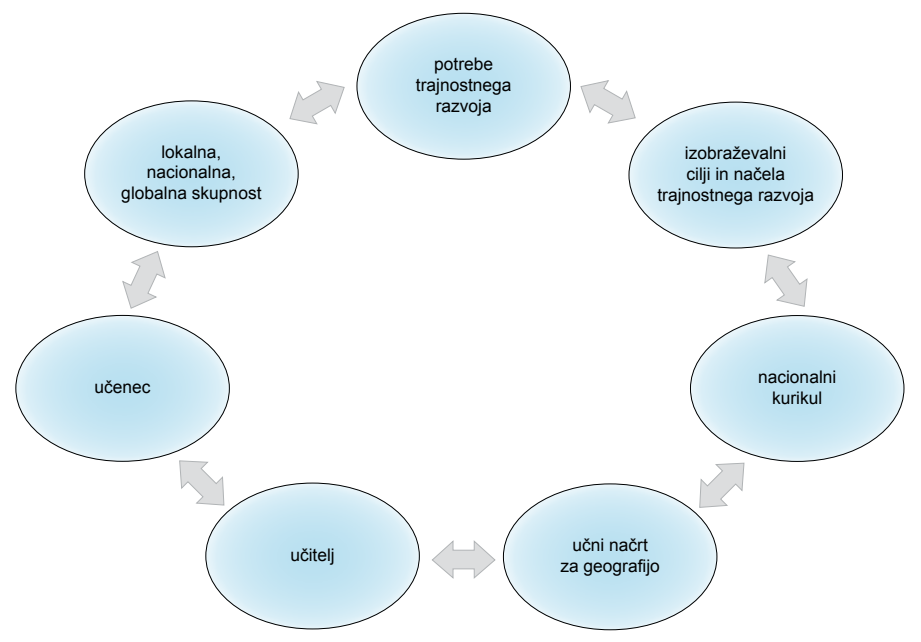

Razumevanje in uresničevanje načel trajnostnega razvoja ni več le del različnih razvojnih dokumentov, temveč postaja vse bolj tudi sestavni del znanj ter vzgojnih vrednot v slovenskih šolah. Leta 2007 so bile v Sloveniji zapisane Smernice vzgoje in izobraževanja za trajnosti razvoj od predšolske vzgoje do univerzitetnega izobraževanja (medmrežje 2). V njih so bila opredeljena ključna področja trajnostnega razvoja, ki vključujejo med drugim državljanstvo, mir, etiko, odgovornost v krajevnem in mednarodnem kontekstu, demokracijo in vladanje, pravičnost, varnost, človekove pravice, zmanjšanje revščine, zdravstvo, enakost spolov, kulturno raznovrstnost, razvoj podeželja in mest, gospodarstvo, proizvodne in potrošniške vzorce, skupno odgovornost, varstvo okolja, upravljanje naravnih virov ter biotsko in pokrajinsko raznovrstnost. 
Odzivanje na tako različne teme v okviru vzgoje in izobraževanja za trajnostni razvoj (VITR) zahteva celosten pristop in ni le dodatek k sedanjemu splošnemu izobraževanju, niti ni njen cilj zgolj in samo varovanje narave, ampak je:

- obsežen, celovit, skladen pedagoški proces, ki vključuje odnos med človekom in naravo ter odnose med ljudmi;

- vodi do razumevanja vsestranske zveze med naravnim, gospodarskim, družbenim in političnim sistemom ter soodvisnosti ljudi, ki živijo v različnih delih sveta;

- skuša dejavno in tvorno reševati sedanja in prihodnja okoljska in družbena vprašanja človeštva (medmrežje 2).

Cilji, ki bodo prispevali k uresničevanju vzgoje in izobraževanja za trajnostni razvoj (VITR), so: zagotoviti normativne podlage, ki podpirajo VITR, usposobiti strokovne delavce v VITR, zagotoviti ustrezna didaktična in druga gradiva za uresničevanje VITR, pospeševati raziskave in razvoj VITR, okrepiti sodelovanje vseh dejavnikov na področju VITR na vseh ravneh (državna, pokrajinska, občinska). V navedenem dokumentu se je Ministrstvo za šolstvo in šport obvezalo, da bo skušalo smernice uresničiti z zagotovitvijo normativnih podlag, ki podpirajo VITR, vključevanjem prvin trajnostnega razvoja v kurikularne dokumente (npr. učne načrte), vključevanjem prvin VITR v preverjanje znanja, zagotavljanjem ustreznih programov nadaljnjega izobraževanja in usposabljanja strokovnih delavcev v vzgoji in izobraževanju, zagotavljanjem razvojno-raziskovalnega dela na področju VITR, vključevanjem VITR kot kazalnika kakovosti na državni ravni, sodelovanjem z različnimi državnimi ustanovami in nevladnimi organizacijami, spodbujanjem sodelovanja s socialnimi partnerji (medmrežje 2).

\section{ZASTOPANOST NAČEL TRAJNOSTNEGA RAZVOJA V UČNIH NAČRTIH GEOGRAFIJE}

Veliko vlogo pri spreminjanju kurikula imajo spremembe izobraževalne filozofije, pri čemer je kurikulum rezultat kompromisa med obstoječimi izobraževalnimi filozofijami (Kliebard; citirano po Reynolds 2000) in spremembami, ki jih želimo vključiti vanje z vidika novih izobraževalnih smernic kot odraza družbenih potreb. Konečnik Kotnikova se sklicuje na Kellya in Gaya, ko navaja (2009), da lahko poteka odločanje o kurikulu pretežno na ravni poučevanja (v tem primeru se čuti močan vpliv učiteljev), na ravni institucije oziroma šole in na državni ravni (npr. vpliv vladnih služb kot so Ministrstvo za šolstvo in šport, Zavod za šolstvo ipd..). K naštetemu bi bilo po mnenju Ivanuš Grmekove (1997) smiselno dodati še posamezne znanstvene discipline, ki bi tudi morale sodelovati pri odločanju o kurikulu.

Pregled razvojnih usmeritev geografskega izobraževanja v slovenskem in evropskem prostoru pokaže, da je zadnje desetletje minulega stoletja prineslo zavedanje, da je potrebno vzpostaviti kvalitetnejše odnose v rabi prostora: spremeniti odnos do okolja, soljudi in prihodnjih rodov (vzgoja za sožitje, multikulturna vzgoja, okoljska vzgoja). Začetek 21. st. tesno poveže šolsko geografijo $\mathrm{z}$ interdisciplinarnimi učnim cilji varovanja okolja za preživetje človeštva in trajnostnega razvoja na lokalnem, regionalnem in planetarnem nivoju (Kolenc Kolnik 2008). 
Tako definirani učni cilji so kot integralni del učnih načrtov po mnenju nekaterih raziskovalcev slovenske šolske geografije (Cigler 2003; Kolenc Kolnik in Resnik Planinc 2006; Polšak 2007; Konečnik Kotnik 2009; Kolenc Kolnik in Konečnik Kotnik 2010) pomembni, če ne že odločilni pri vplivu na sam pouk geografije. Vsekakor pa je pomembno tudi poznavanje učiteljev geografije, njihovih kompetentnosti oziroma poznavanje njihovega sprejemanja ter razumevanja izhodišč in značilnosti prenovljenih učnih načrtov kot ključnih nosilcev učnega procesa.

Prva skupna značilnost kroskurikularnih vzgojno-izobraževalnih ciljev, usmerjenih v izobraževanje za trajnostni razvoj, je poudarek na vrednotah in usposabljanju za praktične dejavnosti in smotrno odločanje, ki naj seveda temelji na kakovostnem, prožnem, dobro razumljenem in povezanem znanju. Med najučinkovitejše načine spodbujanja medpredmetnega povezovanja (Dyrfjord in sod. 2004) se uvrščajo izobraževalni cilji, ki omogočajo razvijanje učenčevih raznolikih kompetentnosti. Le-to temelji na celostnem in kompleksnem pojmovanju geografskega prostora in poudarku na vzročno-posledičnih povezavah med naravnimi in družbenimi dejavniki. Med tipične značilnosti izobraževanja za sonaravni trajnostni razvoj se uvrščajo tudi naslednje: razumevanje vrednot sonaravnega trajnostnega razvoja, razvijanje kritičnega in kreativnega mišljenja, razvijanje sposobnosti samostojnega odločanja ter razvijanje sposobnosti skupinskega dela. Učeči naj bi se usposabljali za razvoj kognitivnih sposobnosti, za izobraževalno fleksibilnost in motiviranost ter intelektualno radovednost in tako krepili psihosocialne spretnosti, ki jih potrebujejo, da bi obvladovali nove učne in življenjske izzive (ESD 2005; Mulchany in Tutiaux-Guillon 2005; Kolenc Kolnik 2007; 2008).

Druga pomembna značilnost in sočasno velika vzgojno-izobraževalna prednost geografije v doseganju ciljev VITR je, da omogoča večplastnost informacij o javnem, poklicnem in osebnem življenju ljudi v različnih fizičnih (naravnogeografski) in socio-ekonomskih (družbenogeografskih) okoljih, kar omogoča učencem spoznati, razumeti in sprejeti državljansko odgovornost za delovanje $\mathrm{v}$ lokalnem, regionalnem, nacionalnem in globalnem prostoru. To pa so osnove za razumevanje pomena odnosov in vrednot pri odločanju, pripravljenosti za odgovorno uporabo znanja o prostoru in osveščanja o prevzemu soodgovornosti zanj. Sposobnost razumevanja stvari z različnih vidikov je za odgovorno državljanstvo, ob upoštevanju različnih stališč posameznika ali naroda, tudi ključnega pomena za intra- in internacionalno razumevanje. Izhodišče je, kot smo v sestavku že poudarili pri opisu značilnosti inovativnega učenja, proaktivna usmerjenost v (zaželeno) prihodnost, v predvidevanje njenega razvoja, oblikovanje vizij, iskanje ter vrednotenje novih, alternativnih zamisli in rešitev.

Skupna značilnost prenosa znanj in veščin različnih izobraževalnih/vzgojnih področij je poudarek na vrednotah (načela trajnostnega razvoja) in usposabljanju za praktične dejavnosti in premišljeno odločanje.

Geografija kot šolski predmet ima zaradi svoje vsebinske večplastnosti posebno identiteto in interdisciplinarno usmerjene cilje, tako da omogoča spodbujanje učenja za odgovorno državljanstvo s treh ključnih področij akcijskih kompetenc: s področja kognicije (znanje in razumevanje), dejavnosti (spretnosti in veščine) ter odnosov (vrednote in stališča). V procesu geografske vzgoje in izobraževanja pridobivajo dijaki in učenci sposobnosti za razvoj kritične osebnosti ob spodbujanju razumevanja delovanja človeške družbe v okvirih naravnih 
danosti z ustrezno, na znanju in razumevanju temelječo kritično distanco. Učeči se pridobivajo sposobnosti za vrednotenje protislovij od lokalnega, regionalnega do planetarnega okolja, obenem pa se usposabljajo za prepoznavanje nujnosti trajnostnega razvoja ter odgovornosti do ohranjanja kvalitete okolja za prihodnje generacije.

Slika 2: Usmerjenost razvoja kompetenc za doseganje aktivnega državljanstva v izobraževanju za trajnostni razvoj

Figure 2: Targeting the development of competences to achieve active citizenship in education for sustainable development

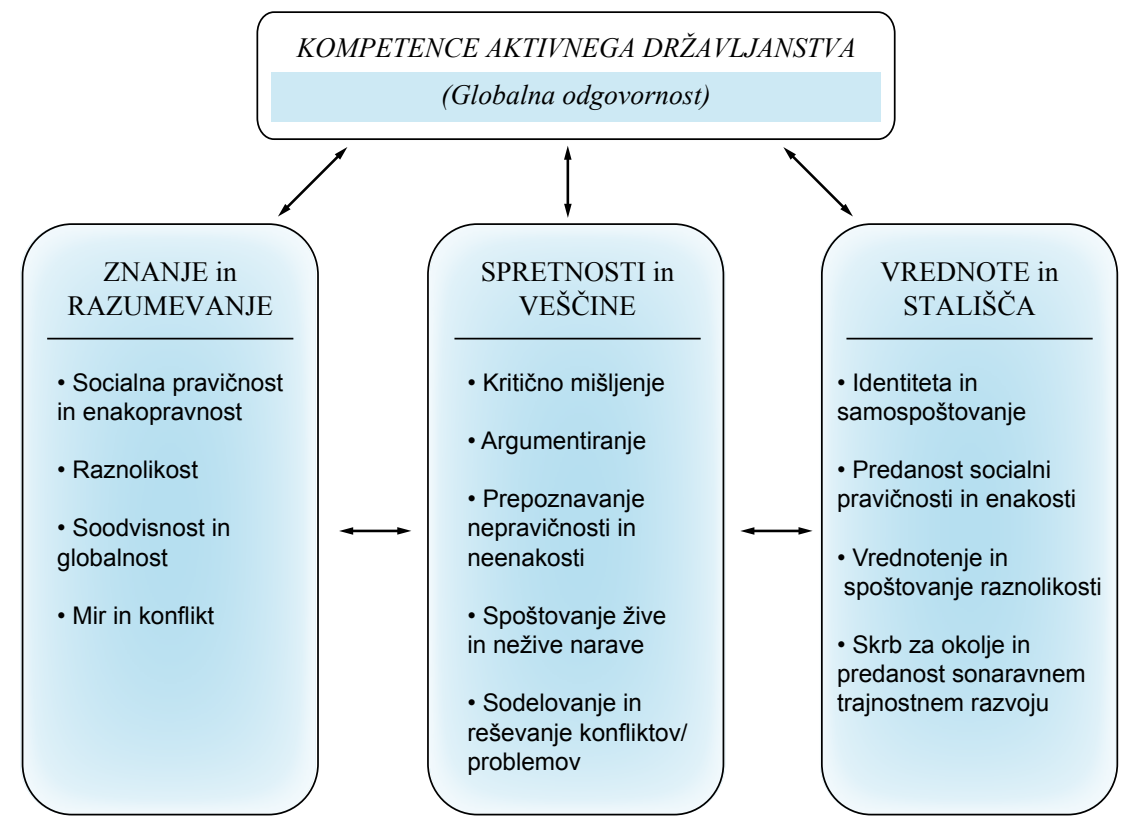

Viri/Sources: ESD 2005; Mulchany in Tutiaux-Guillon 2005; Kolenc Kolnik 2007; 2008

Spirala vzgoje in izobraževanja po načelih trajnostnega razvoja se pričenja pri socializaciji kot pomembnem predpogoju za uspešno delo in zato so priporočene oblike učnega dela, kjer se uči drug od drugega (učenci od učitelja, staršev, strokovnih sodelavcev, pa tudi učitelj od staršev, strokovnih sodelavcev in učencev, nadalje straši od učencev, učitelja itd.,), zato tudi vedno večji poudarek na aktivnem vključevanju lokalne skupnosti v različne oblike formalnega izobraževanja kot osnove za participatorno izobraževanje v demokratičnih procesih odločanja (vključevanje zunanjih sodelavcev, npr. staršev, strokovnjakov z različnih področij ali pa krajanov kot poznavalcev lokalne skupnosti, vsi kot partnerji v učnem procesu). Kompetence aktivnega državljanstva se najbolje razvijajo ob prepletanju izkušenj in znanja. 


\section{ZASTOPANOST NAČEL VZGOJE IN IZOBRAŽEVANJA ZA TRAJNOSTNI RAZVOJ V UČNEM NAČRTU ZA GEOGRAFIJO $\checkmark$ SPLOŠNIH GIMNAZIJAH Z 2I0-URNIM PROGRAMOM}

Za doseganje ciljev VITR so v Smernicah vzgoje in izobraževanja za trajnostni razvoj od predšolske vzgoje do univerzitetnega izobraževanja na Ministrstvu za šolstvo in šport (medmrežje 2) opredelili enajst načel:

1. načelo odgovornega ravnanja do sebe, družbenega in naravnega okolja: VITR zahteva odgovoren odnos posameznika do samega sebe, soljudi in narave;

2. načelo obravnave TR $\mathrm{z}$ vidika etičnih razsežnosti, vključno z vprašanji enakopravnosti, solidarnosti in medsebojne odvisnosti med pripadniki ene generacije in med različnimi generacijami;

3. načelo spoštovanja človekovih pravic: spoštovanje človekovih pravic je bistveno načelo trajnostnega razvoja. VITR je zato v tesni povezavi z vzgojo za človekove pravice, katere cilj je razvijanje in razumevanje odgovornosti za uresničevanje teh pravic v vsaki skupnosti in družbi nasploh. V tem smislu prispeva k dolgoročnemu preprečevanju kršenja človekovih pravic in nasilnih sporov, k spodbujanju enakosti in trajnostnega razvoja ter povečanju udeležbe ljudi v postopkih odločanja znotraj demokratičnega sistema;

4. načelo integrativnosti elementov VITR (povezovanje okoljskih, gospodarskih in socialnih vprašanj): VITR razširja zasnovo okoljskega izobraževanja in vedno bolj obravnava vse več različnih razvojnih tem in druge ciljne oblike izobraževanja. Zato bi bilo treba okoljsko izobraževanje izpopolniti in dopolniti z izobraževalnimi področji, ki se dotikajo gospodarskih in družbenih vprašanj;

5. načelo celostnega pristopa VITR: ključne teme trajnostnega razvoja so zelo raznovrstne, zato je za obravnavanje takih tem potreben celosten pristop;

6. načelo medkulturnega dialoga: nujna je odprta, spoštljiva in enakopravna izmenjava pogledov in mnenj med posamezniki oziroma skupinami različnih kulturnih ozadij, ki posledično prispeva h globljemu razumevanju različnih svetovnih nazorov, vrednot in razmišljanj. Tako lahko različne kulture mirno in ustvarjalno soobstajajo, razvijajo občutek skupnosti in pripadnosti ter gojijo vzajemno spoštovanje in razumevanje drug drugega;

7. načelo sistematičnega, kritičnega in ustvarjalnega razmišljanja o TR: kot temeljni pogoj za ukrepe za TR bi bilo treba otroke oziroma učence in dijake na vseh stopnjah spodbujati k sistematičnemu, kritičnemu in ustvarjalnemu mišljenju in razmišljanju v krajevnih, pokrajinskih, državnih in svetovnih okvirih;

8. načelo ozaveščanja o TR: sodobni družbeni in gospodarski razvoj ter okoljska vprašanja zahtevajo znanje in ravnanje celotne družbe po načelih TR;

9. načelo vseživljenjskega učenja za TR celotne populacije: VITR je vseživljenjski proces, ki poteka od zgodnjega otroštva do odrasle dobe ter sega prek okvirov formalnega izobraževanja;

10. načelo partnerstva na lokalnem, regionalnem, nacionalnem in mednarodnem nivoju: VITR bi moral upoštevati različne lokalne, regionalne, nacionalne in mednarodne razmere ter svetovni okvir in si prizadevati za ravnovesje med različnimi interesi; 
11. načelo socialnega partnerstva: za VITR je nujno povezovanje partnerjev, kot so strokovni delavci v vzgoji in izobraževanju in otroci/učenci/dijaki z državno in občinsko oblastjo ter s predstavniki civilne družbe. Predvsem pa je treba vključiti v VITR predstavnike gospodarstva in znanosti, saj to omogoča gospodarsko blaginjo v skladu z znanstvenimi spoznanji.

Izhodišče za uresničevanje ciljev VITR v šolah dajejo učni načrti in zato smo, da bi preverili njihovo vključenost v pouk geografije, analizirali enega izmed načrtov za pouk geografije. Izbrali smo prenovljeni učni načrt za geografijo v gimnazijah z 210-urnim programom, ki se v šolah izvaja drugo leto (medmrežje 3). Učni načrt smo, na osnovi deskriptivne metode pedagoške dokumentacije, analizirali po številu in vsebini splošnih učnih ciljev ter ključnih kompetencah tako, da smo proučili vključenost enajstih načel VITR, definiranih v Smernicah VITR (medmrežje 2), v učnih vsebinah in učnih ciljih.

Analiza številčne zastopanosti načel VITR pokaže, da so vsa področja načel VITR zastopana vsaj z enim učnim ciljem in sicer: $z$ enim učnim ciljem so zastopana štiri načela VITR, z dvema učnima ciljema štiri načela, s tremi učnimi cilji eno načelo in s šestimi učnimi cilji eno načelo VITR. Prav pri slednjem, kjer je s šestimi učnimi cilji zastopano načelo integrativnosti elementov trajnostnega razvoja, se kaže velika izobraževalna prednost geografije in njena povezovalna naravnanost $\mathrm{v}$ preučevanju narave in družbe.

Analiza možnosti spodbujanja razvoja ključnih kompetenc dijakov pa pokaže, da so te vključene v učne vsebine in učne cilje preučevanega učnega načrta geografije za gimnazije v desetih načelih VITR. Edino načelo, kjer tega ni bilo zaznati, je načelo ozaveščanja o TR (širše: sodobni družbeni in gospodarski razvoj ter okoljska vprašanja zahtevajo znanje in ravnanje celotne družbe po načelih TR).

Mnenja smo, da je prenova analiziranega učnega načrta za gimnazije ustrezno sledila smernicam izobraževanja za trajnostni razvoj, pri tem pa tudi opažamo določene pomanjkljivosti, zlasti na področju vključevanja vzgojnih ciljev (državljanska vzgoja, vzgoja za sožitje, multikulturna vzgoja, okoljska vzgoja ipd.), ki omogočajo razvoj kompetenc odgovornega ravnanja državljanov in ozaveščenosti celotne družbe za trajnostni razvoj.

\section{SKLEP}

Med osnovne stalnice razvoja šolske geografije uvrščamo nenehno sledenje in prilagajanje družbenim (izobraževalnim, ekonomskim, socialnim ipd.) potrebam in razvoju geografske znanosti. Za doseganje ciljev vzgoje in izobraževanja za trajnostni razvoj morajo biti v sozvočju vsi elementi in akterji izobraževalnega procesa, kar pa zahteva temeljit razmislek o njihovi današnji vlogi in tudi določene spremembe $v$ celotni nacionalni izobraževalni politiki. Med slednje uvrščamo tudi kurikule in učne načrte.

Če smo s prenovo geografskih učnih načrtov kot temeljne pedagoške dokumentacije pouka geografije lahko zadovoljni z vidika njihovega sledenja sodobnim načelom vzgoje in izobraževanja za trajnostni razvoj, nas pomembne spremembe, v pred tremi leti prenovljenih geografskih učnih načrtih za osnovno kot tudi srednješolsko stopnjo, še čakajo. To zlasti velja za prenovo pouka geografije z vidika izobraževalne filozofije, ki je tudi v pojmovanju, da 
učenci in učitelji niso samo realizatorji učnih načrtov ali pa porabniki znanja, ki ga proizvajajo drugi (npr. njihovi učitelji in didaktična gradiva), ampak morajo biti tudi proizvajalci in soustvarjalci tega znanja. Namesto 'reaktivnosti', torej reagiranja na izobraževalne spremembe oziroma novosti, je potrebno, da razvijejo proaktivno sposobnost kot izhodišče za inovativno učenje. Analiza izbranega učnega načrta za gimnazije z 210-urnim programom je pokazala, da le-ta daje podlage za inovativno učenje, ki spodbuja vzgojo in izobraževanje za trajnostni razvoj. Prav tako spodbuja anticipatorno učenje (spodbujanje ustvarjalnosti v smislu dolgoročnega načrtovanja prihodnosti in prevzemanja odgovornosti za lastne odločitve) ter participatorno učenje (posameznikova aktivnost in skupinsko sodelovanje pri oblikovanju problemsko usmerjenih vprašanj ter predvidevanju alternativnih rešitev zanje), ki prav tako neposredno podpirata uresničevanje načel vzgoje in izobraževanja za trajnostni razvoj. Sedaj se odpira vprašanje, kako se bodo pedagoški dokumenti (npr. učni načrti) uspešno udejanjili v pedagoški praksi.

\section{Viri in literatura}

Cigler, N. 2003: Geografija v 4. letniku gimnazije. Priprava na maturo. Geografija v šoli 12, 3, str. 9-14. Ljubljana.

Dyrfjord, K., Fumat, Y., Pergar Kuscer, M., Andersen, R. 2004: Citizenship education and identity in courses for those who will work with pre-school children. CiCe Professional Guidelines 1. London.

Hawkes, J. 2001: The fourth pillar of sustainability: Culture's essential role in public planning. Common Ground. Melbourne.

Houtsonen, L. 2004: Education for sustainability. Sustainable developement and intercultural sensitivity. New approaches for a better world. Universidade Aberta. Lisboa.

Interboard education for sustainable development group 2005: Education for sustainable development. Good practice guide for primary, secondary and special schools. Curriculum Advisory \& Support Service. Northern Ireland.

Ivanuš Grmek, M. 1997: Kurikularno načrtovanje na višji stopnji obvezne osnovne šole. Doktorska disertacija. Oddelek za geografijo, Filozofska fakulteta Univerze v Ljubljani. Ljubljana.

Kolenc Kolnik, K., Resnik Planinc, T. 2006: Izzivi prenove gimnazijskega programa z vidika geografskega izobraževanja. Geografski obzornik 53, 4, str. 48-56. Ljubljana.

Kolenc Kolnik, K., 2007: Proaktivnost in terensko delo v izobraževanju za trajnostni razvoj. Revija za geografijo 2, 2, 24-32. Maribor.

Kolenc Kolnik, K. 2008: Razvoj geografskih kurikulov in izobraževalni potencial geografije na začetku 21. stoletja. Dela 29, str. 77-88. Ljubljana.

Kolenc Kolnik, K., Konečnik Kotnik, E. 2010. Geografski kurikul kot proces. Posodobitev pouka v gimnazijski praksi. V: Geografija (ur. A. Polšak), str. 13-28. Zavod RS za šolstvo in šport. Ljubljana.

Konečnik Kotnik. E. 2009: Vrednotenje učnega načrta za pouk geografije v splošni gimnaziji v Sloveniji z vidikov družbenih potreb, izobraževalnih smernic in geografske znanosti. Doktorska disertacija. Filozofska fakulteta Univerze v Mariboru. Maribor. 
Medmrežje 1: http://www.unesco.si/projekti-in-aktivnosti izobrazevanje-za-trajnostni-raz voj.html (1.9.2008).

Medmrežje 2: Smernice vzgoje in izobraževanja za trajnostni razvoj od predšolske vzgoje do univerzitetnega izobraževanja. Ministrstvo za šolstvo in šport, 2007. http://www.mss. gov.si/si/delovna_podrocja/razvoj_solstva/vzgoja_in_izobrazevanje_za_trajnostni_razvoj/ (1.9.2010)

Medmrežje 3: Učni načrt Geografija: gimnazija: splošna, klasična, ekonomska gimnazija: obvezni predmet (210 ur), matura (105 ur). Ministrstvo za šolstvo in šport, Zavod RS za šolstvo. 2008. http://portal.mss.edus.si/msswww/programi2008/programi/media/pdf/ un_gimnazija/geografija_spl_gimn.pdf(1.9.2010)

Mulchany, C., Tutiaux-Guillon, N. 2005: Guidelines on citizenship education for sustainable development. CiCe Guidelines 9. London.

Polšak, A. 2007: Medpredmetno povezovanje in učni načrt. Geografija v šoli 16, 2, str. 33-43. Ljubljana.

Reynolds, R. 2000: A model for research syllabus developement and curriculum change. Paper at the AARE Conference. University of Sydney. Sydney.

\section{SCHOOL GEOGRAPHY FROM THE VIEWPOINT OF UPBRINGING AND EDUCATION FOR SUSTAINABLE DEVELOPMENT}

\section{Summary}

One of the basic characteristics of school geography is its constant adjusting to the social (educational, economic, etc.) needs and to the development of geography as a science. To achieve the goals of upbringing and education for sustainable development, all the elements and agents of the educational process need to be sound with each other, which calls for a thorough consideration of their current role as well as for certain changes in the entire national educational policy. The latter include also the guidelines of upbringing and education for sustainable development on all the educational levels.

We can be satisfied with the revised geography syllabi as a basic pedagogical documentation for geography classes from the point of view of their accordance with the principles of education for sustainable development. However, important changes in the geography syllabi for primary and secondary schools, which were revised three years ago, are still ahead of us. This refers in particular to the revision of geography classes from the point of view of educational philosophy, according to which students and teachers should not only carry out the syllabi or consume knowledge produced by others (the teachers and didactic materials), but also produce and co-create this knowledge. Instead of 'reaction' to the educational changes and novelties, they need to develop a proactive attitude as a starting point for innovative learning. Innovative learning, which encourages the upbringing and education for sustainable development, is composed of anticipatory learning (encouragement of creativity in the sense of long term planning of the future and assuming responsibility for one's own decisions) and participatory learning (an individual's active involvement and 
participation in group formation of problem directed questions and anticipation of alternative solutions for these questions), and directly supports the implementation of the educational principles for sustainable development. Now we are coming to the very important question of connecting teaching documents and learning practice. 